\title{
SEBARAN DAERAH PENANGKAPAN IKAN TUNA DI SAMUDERA HINDIA
}

\author{
Wudianto", Karsono Wagiyo"), dan Berbudi Wibowo"
}

\begin{abstract}
ABSTRAK
Tuna merupakan komoditas perikanan laut yang sangat penting karena dapat menyumbang perolehan devisa. Jenis ikan ini memiliki penyebaran yang sangat luas dan biasanya melakukan ruaya jauh. Di Indonesia penangkapan ikan tuna dilakukan secara komersial mulai tahun 1970-an yang dirintis oleh PT Perikanan Samudera Besar. Saat ini banyak perusahaan perikanan yang melakukan penangkapan tuna khususnya dengan alat tangkap longline. Terdapat tiga tempat pendaratan utama kapal longline tuna yaitu Benoa, Cilacap, dan Jakarta. Sebagian besar kapal longline tuna melakukan penangkapan di perairan Samudera Hindia. Dari hasil pengamatan dengan cara mengikuti operasi kapal komersial terlihat bahwa sebagian besar longline tuna Indonesia beroperasi di luar ZEEI. Terdapat kecenderungan bahwa nilai hook rate tinggi diperoleh di perairan luar ZEEI. Komposisi hasil tangkapan longline tuna bervariasi tergantung dari waktu dan daerah penangkapan, namun jenis tuna mata besar (bigeye tuna. Thunnus obesus) merupakan jenis dominan pada setiap trip penangkapan. Ukuran ikan tuna yang tertangkap relatif besar, yakni dengan panjang cagak antara 40-180 cm. Jenis madidihang dan mata besar lebih senang pada suhu permukaan laut yang hangat sedang albakora pada suhu yang agak dingin.
\end{abstract}

\section{ABSTRACT: Distribution of tuna fishing ground in the Indian Ocean waters. By: Wudianto, Karsono Wagiyo, and Berbudi Wibowo}

Tunas play an important role in international market for source of Indonesia foreign exchange earning. These large pelagic fishes have wide spread distribution and migration. Commercial tuna fishing in Indonesian has been carried out since 1970s by PT. Perikanan Samudera Besar. A number of fishing companies operates hundreds of longliners since afterward in the Indian Ocean waters. There are three main landing sites of tuna longliners, namely Benoa, Cilacap, and Jakarta. The results show that most of those tuna longliners operated out side of the Indonesian EEZ with higher hook rate than within EEZ waters. Catch composition of tuna varied by time and fishing ground but dominated bigeye tuna (Thunnus obesus). The average size of the catch was relatively high, i.e., $40-180 \mathrm{~cm}$ in fork lengh. Yellowfin and bigeye prefer the warm surface water, whereas albacore is in the colder ones.

KEYWORDS: tuna, fishing ground, hook rate, Indian Ocean

\section{PENDAHULUAN}

Tuna memiliki nilai ekonomis penting untuk memenuhi di dalam negeri maupun pasar internasional sebagai sumber devisa. Tuna tergolong jenis scombrid yang sangat aktif berenang dan menyebar di perairan dekat pantai sampai ke perairan oseanik. Menurut Blackburn (1965) tuna dapat digolongkan menjadi 3 kelompok besar berdasarkan wilayah penyebarannya yakni; (1) jenis tuna yang hidup di perairan oseanik, seperti: tuna sirip biru, albakora, mata besar, dan madidihang; (2) yang hidup tidak jauh dari pantai, seperti: cakalang dan tongkol; dan (3) yang belum diketahul penyebarannya, seperti: Allothunus fallai.

Sebagian besar jenis ikan tuna memiliki penyebaran yang sangat luas dan melakukan ruaya yang jauh mencapai ribuan mil. Selain itu, tuna juga merupakan spesies yang kosmopolitan dan senang membentuk gerombolan. Scott (1969) menyatakan bahwa terdapat dua asosiasi gerombolan ikan tuna di laut yakni: (1) yang berasosiasi dengan binatang laut lainnya seperti lumba-lumba, dan (2) yang berasosiasi dengan benda yang hanyut di laut seperti balok kayu atau rumpon.

Penyebaran dan kelimpahan ikan tuna ternyata sangat dipengaruhi oleh beberapa parameter oseanografi. Variasi suhu perairan memiliki peran penting di dalam menentukan penyebaran ikan tuna secara spasial (Laevastu \& Rosa, 1963; Squire, 1982). Jenis madidihang memiliki penyebaran secara vertikal yang dibatasi oleh dalamnya thermoklin (Longhurst \& Pauly, 1987), sedangkan jenis albakora dan mata besar biasanya hidup di lapisan perairan di bawah thermoklin (Laevastu \& Hayes, 1982).

Penangkapan ikan tuna di Indonesia secara industri dimulai sejak awal tahun 1970-an yang dirintis oleh PT. Perikanan Samudera Besar (Simorangkir, 2000). Perkembangan penangkapan tuna berlangsung sangat cepat terutama dalam kurun waktu sepuluh tahun terakhir ini. Tercatat sekitar 800 armada kapal rawai tuna berpangkalan di 3 pusat pendaratan utama yakni Benoa-Bali, Cilacap, dan

\footnotetext{
-) Peneliti pada Balai Riset Perikanan Laut, Jakarta

*) Peneliti pada Pusat Riset Perikanan Tangkap, Jakarta
} 
Muara Baru. Sebagian besar kapal rawai tuna melakukan penangkapan di perairan Samudera Hindia.

Mengingat penangkapan ikan tuna dilakukan oleh beberapa jenis armada di wilayah perairan yang berbeda, maka interaksi antar perikanan merupakan masalah yang dapat mempengaruhi produksi tuna di masa mendatang. Pengelolaan sumber daya ikan tuna tidak dapat dilaksanakan oleh Indonesia sendiri, sehingga perlu adanya kerja sama dengan negara lain yang terlibat langsung dalam penangkapan. Dengan adanya keterlibatan negara lain dalam mengelola sumber daya tuna, maka diperlukan adanya kuota penangkapan.

Untuk itu diperlukan informasi tentang penyebaran daerah penangkapan, komposisi jenis, aspek biologi ikan, dan pengaruh faktor lingkungan terhadap kelimpahan ikan tuna. Penelitaian ini ditujukan untuk memenuhi kebutuhan tersebut.

\section{BAHAN DAN METODE}

\section{Pengumpulan Data}

Pengumpulan data dilakukan di tiga tempat pendaratan utama, yaitu: Benoa, Cilacap, dan Muara Baru selama tahun 2001-2002. Sampling dilakukan dengan cara mengikuti kapal komersial yang beroperasi di perairan Samudera Hindia.

\section{Jenis Data yang Dikumpulkan}

a. Data operasional penangkapan (daerah penangkapan dan komposisi hasil tangkapan).

b. Data biologi (frekuensi ukuran panjang dan aspek reproduksi). Aspek reproduksi terutama yang berkaian dengan kematangan seksual dengan menggunakan acuan Holden \& Raitt, 1974.

c. Data parameter oseanografi meliputi suhu, salinitas, dan plankton yang diperoleh dengan cara sampling di laut saat mengikuti kapal penangkapan ikan.

\section{Analisis Data}

Beberapa metode analisis diterapkan untuk berbagai parameter guna memperoleh informasi yang diperlukan, yaitu

- Analisis secara grafikal untuk menggambarkan karakteristik biologi (perubahan struktur ukuran panjang dan aspek reproduksI).

- Analisis statistik terhadap sebaran frekuensi panjang dan tingkat kematangan gonad.

- Analisis kelimpahan ikan yang dinyatakan dalam nilai laju pancing (hook rate) yaitu jumlah ikan yang tertangkap oleh 100 mata pancing yang dioperasikan.
- Analisis hubungan antara parameter oseanografi khususnya suhu permukaan laut dengan penyebaran dan kelimpahan tuna.

\section{HASIL DAN BAHASAN}

\section{Penyebaran Daerah Penangkapan Ikan Tuna}

Selama penelitian tahun 2001 telah dilakukan pengamatan secara langsung dengan mengikuti operasi kapal longline tuna milik nelayan perseorangan dan milik perusahaan sebanyak enam trip, sedangkan pada tahun 2002 sebanyak lima trip dari tiga tempat pendaratan, yaitu: Muara Baru, Cilacap, dan Benoa. Pengamatan dari Muara Baru dilakukan pada bulan Mei, Nopember 2001, dan Agustus 2002 dengan daerah penangkapan di perairan barat Sumatera (Gambar 1). Pengamatan dari Cilacap dilakukan pada bulan Agustus dan Oktober tahun 2001 dan bulan Mei-Juni, September, dan Desember tahun 2002. Sedangkan pengamatan dari Benoa Bali dilakukan pada bulan Agustus dan Desember 2001, serta Juni 2002. Penyebaran daerah penangkapan longline tuna yang berasal dari Cilacap dan Benoa hampir sama yaitu di perairan selatan Jawa Tengah antara $108^{\circ}-118^{\circ}$ BT dan $8^{\circ}-22^{\circ}$ LS (Gambar 1).

Sebagian besar kapal longline tuna (>70\%) melakukan penangkapan di luar perairan ZEEI. Informasi ini sangat penting terutama untuk mendukung pengembangan dan pengelolaan perikanan selanjutnya. Ternyata laju pancing (hook rate) di luar perairan ZEEI lebih besar daripada penangkapan di dalam ZEEI. Di samping itu kapal longline tuna yang beroperasi di luar ZEEI lebih berpeluang untuk dapat menangkap tuna sirip biru selatan (southern bluefin tuna, SBT) yang memiliki harga jual paling tinggi dibandingkan jenis ikan tuna lainnya, terutama bila memenuhi standar kualitas untuk sashimi.

\section{Komposisi Jenis Hasil Tangkapan}

Komposisi hasil tangkapan sangat bervariasi baik dilihat dari daerah atau waktu penangkapan. Pada bulan $\mathrm{Mel} 2001$ di perairan barat Sumatera dengan mengoperasikan 1.215 mata pancing dari 7 kall operasi penangkapan tertangkap ikan tuna 107 ekor $(40 \%)$ dari total hasil tangkapan. Secara rincl komposisi jenis Ikan tuna adalah sebagal berlkut: madidlhang (Thunnus albacares) 64 ekor (23,5\%), mata besar (Thunnus obesus) 34 ekor (12,6\%), dan albakora (Thunnus alalunga) 9 ekor (4\%), Pada operas| penangkapan bulan Nopember 2001 dengan daerah penangkapan dl barat daya Selat Sunda dan dengan jumlah mata pancing 1.200 buah sebanyak 13 stasiun penangkapan tertangkap 62 ekor tuna $(32,8 \%)$ dengan rincian madidihang 24 ekor $(12,7 \%)$, mata besar 25 ekor $(13,2 \%)$, dan albakora (Thunnus alalunga) 13 ekor $(6,9 \%)$. Jika dilihat dari nilai laju 


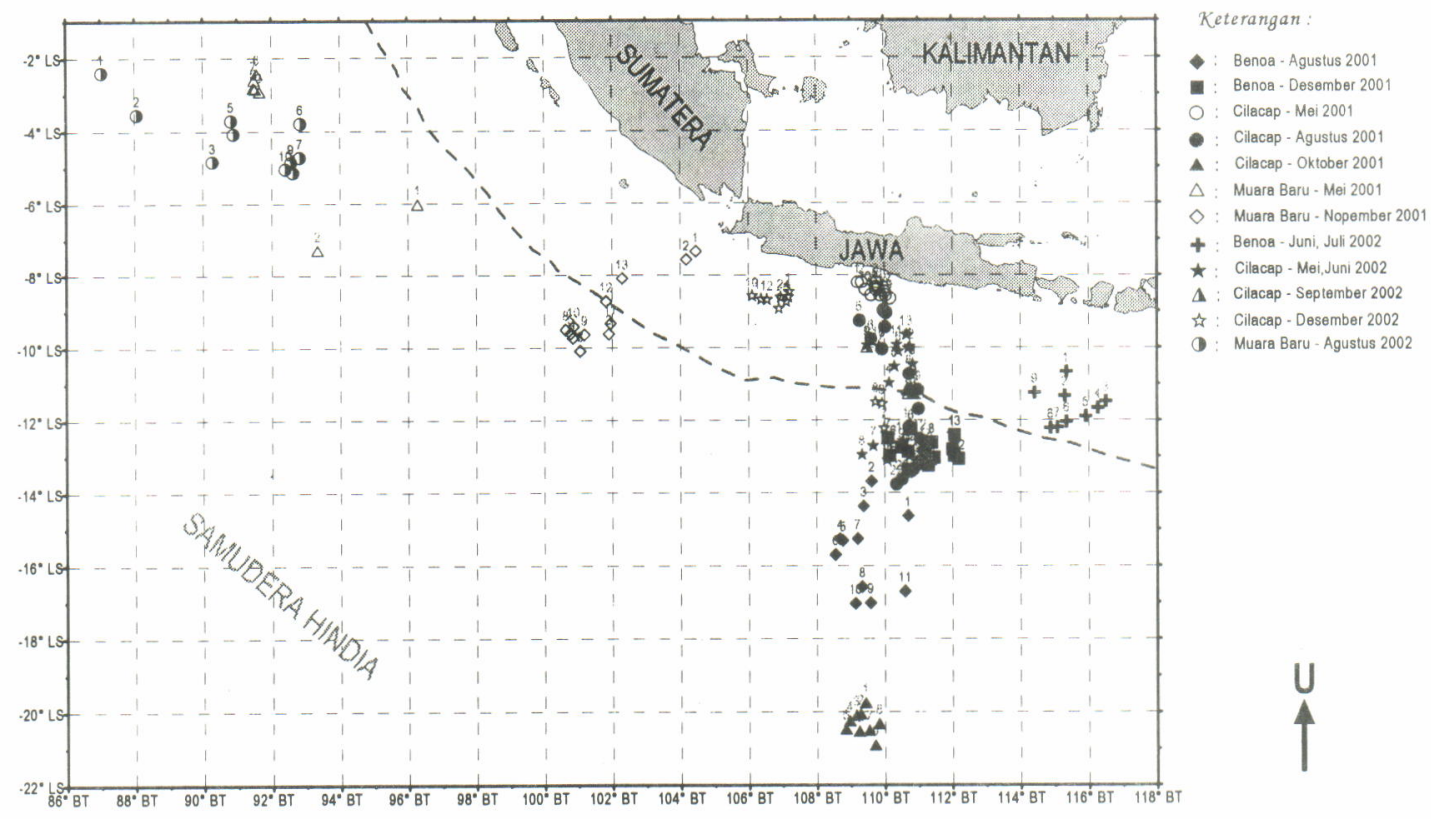

Gambar 1. Penyebaran daerah penangkapan longline tuna di perairan Samudera Hindia pada sampling (2001-2002).

Figure 1. Distribution of tuna longline fishing ground in the Indian Ocean (2001-2002)

tangkap yang dapat digunakan sebagai indikator kelimpahan relatif ikan tuna maka dapat dikatakan daerah penangkapan di sebelah barat Sumatera lebih potensial daripada di perairan barat daya Selat Sunda. Di sini faktor musim juga perlu diperhatikan; pada bulan Mei terdapat kecenderungan memiliki laju tangkap lebih tinggi daripada bulan Nopember.

Seperti dijelaskan di atas bahwa daerah penangkapan longline tuna yang berbasis di Benoa dan Cilacap bercampur di suatu perairan di sekitar 8$22^{\circ}$ LS. Pada bulan Agustus 2001 daerah penangkapan longline tuna yang berasal dari Cilacap sebagian berada di wilayah perairan ZEEI, tetapi yang berasal dari Benoa di luar ZEEI. Dengan mengoperasikan 1.300 mata pancing pada 22 stasiun penangkapan, longline tuna yang berasal dari Cilacap mampu menangkap 193 ekor tuna (19\%) dengan komposisi mata besar sebanyak 87 ekor $(8,5 \%)$ dilkuti albakora sebanyak 57 ekor $(6 \%)$, dan madidihang sebanyak 40 ekor (4\%). Bagi kapal longline tuna yang berasal dari Benoa yang beroperasi agak ke selatan dengan 11 stasiun penangkapan mengoperasikan 1.200 mata pancing memperoleh ikan tuna sebanyak 117 ekor (42\%) dengan komposisi jenis: mata besar sebanyak 95 ekor (34\%), albakora 18 ekor $(6,5 \%)$, dan madidihang 4 ekor $(1,5 \%)$. Di sini terlihat bahwa dari kedua longline tuna yang diamati menunjukkan jenis mata besar merupakan spesies dominan pada bulan Agustus khususnya di perairan selatan Jawa Tengah.

Pada bulan Oktober daerah penangkapan tuna yang berasal dari Cilacap bergeser ke arah selatan mencapai $20^{\circ}-21^{\circ} \mathrm{LS}$, sedangkan yang dari Benoa yang beroperasi pada bulan Desember posisinya hampir sama dengan posisi bulan Agustus. Jumlah mata pancing yang dioperasikan pada bulan Oktober berkisar antara 800-1.125 buah dengan jumlah stasiun 7 lokasi. Hasil tangkapan tuna sebanyak 142 ekor $(67 \%)$ dengan komposisi jenis: albacore 121 ekor $(57 \%)$, madidihang 17 ekor $(8 \%)$, mata besar 8 ekor $(1,5 \%)$, dan SBT 2 ekor $(1,5 \%)$. Pada bulan Desember longline tuna yang berasal dari Benoa mengoperasikan 1.105 buah mata pancing pada 14 stasiun penangkapan dan mendapatkan hasil tangkapan tuna sebanyak 46 ekor $(39 \%)$. Terdapat 2 jenis Ikan tuna yang tertangkap yaitu madidihang 4 ekor $(4 \%)$ dan mata besar 42 ekor $(35 \%)$.

Dari hasil penelitian dapat diketahui bahwa kelimpahan tuna di perairan Samudera Hindia berfluktuasi berdasarkan waktu dan daerah penangkapan. Besaran kelimpahan yang dinyatakan dalam indeks kelimpahan berupa laju pancing (hook rate) dari masing-masing lokasi dan waktu yang berbeda disajikan pada Tabel 1.

Nilai laju pancing tinggi terjadi pada Oktober 2001, yakni kapal yang beroperasi dari Cilacap $(1,59)$ dan pada bulan Mei 2001 kapal yang berasal dari Muara Baru $(1,28)$. Kapal lain yang diamati pada bulan Agustus, Nopember, dan Desember mendapatkan nilai laju pancing ikan tuna dibawah 1 yang berkisar antara 0,30-0,88. Laju pancing jenis ikan lain yang cukup tinggi terjadi pada bulan Agustus, yakni kapal yang berasal dari Cilacap mencapai 2,91 dengan jenis tangkapan dominan cucut dengan berbagai spesies.

\section{Ukuran Tuna}

Pengukuran panjang ikan dilakukan terhadap semua jenis ikan tuna yang tertangkap, namun di 
Tabel 1. Komposisi dan laju pancing longline tuna menurut lokasi dan waktu pengoperasian di perairan Samudera Hindia

Table 1. Spesies composition and hook rate of tuna longline according to the location and time of operation of Indian Ocean

\begin{tabular}{|c|c|c|c|c|c|c|c|c|}
\hline \multirow[t]{2}{*}{$\begin{array}{l}\text { Basis } \\
\text { Kapal } \\
\text { Harbour }\end{array}$} & \multirow[t]{2}{*}{$\begin{array}{c}\text { Bulan } \\
\text { Pengoperasian } \\
\text { Month of Operation }\end{array}$} & \multicolumn{5}{|c|}{$\begin{array}{c}\text { Komposisi Jenis Tuna } \\
\text { Tuna Species Composition } \\
(\%)\end{array}$} & \multicolumn{2}{|c|}{ Hook Rate } \\
\hline & & YFT & BET & ALB & SBT & LTT & ZEE & outside ZEE \\
\hline \multirow{3}{*}{$\begin{array}{l}\text { Muara } \\
\text { Baru }\end{array}$} & Mei-01 & 58,75 & 31,25 & 10 & 0 & 0 & & 1,28 \\
\hline & Nop-01 & 38,72 & 40,24 & 21,04 & 0 & 0 & 0,38 & 0,4 \\
\hline & Agust- 02 & 46,51 & 41,86 & 11,63 & 0 & 0 & & 0,86 \\
\hline \multirow[t]{4}{*}{ Cilacap } & Agust-01 & 21,05 & 44,74 & 31,58 & 2,63 & 0 & 0,64 & 0,7 \\
\hline & Okt-01 & 11,94 & 2,24 & 85,07 & 2,24 & 0 & & 1,59 \\
\hline & $\begin{array}{l}\text { Mei-Juni } 2002 \\
\text { Sep-02 }\end{array}$ & $\begin{array}{l}71,13 \\
19,01\end{array}$ & $\begin{array}{c}8,2 \\
4,13\end{array}$ & $\begin{array}{l}14,75 \\
76,03\end{array}$ & $\begin{array}{c}0 \\
0,00\end{array}$ & $\begin{array}{c}0 \\
0,00\end{array}$ & 0,46 & $\begin{array}{l}0,36 \\
1,48\end{array}$ \\
\hline & Des-02 & 33,33 & 49,02 & 17,65 & 0,00 & 0,00 & 0,87 & \\
\hline \multirow[t]{3}{*}{ Benoa } & Agust-01 & 3,57 & 54,84 & 15,48 & 0,00 & 0,03 & & 0,4 \\
\hline & Des-01 & 8,7 & 91,3 & 0 & 0 & 0 & & 0,3 \\
\hline & Jun-02 & 16,13 & 16,13 & 67,74 & 0,00 & 0,00 & 0,83 & \\
\hline
\end{tabular}

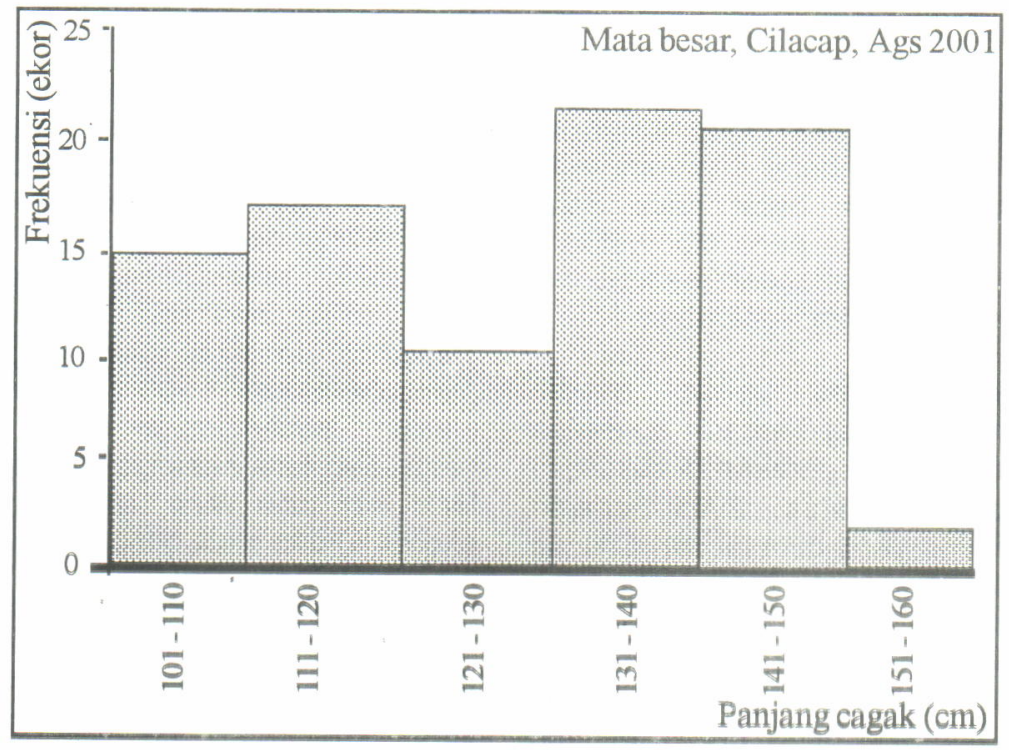

Gambar 2. Sebaran panjang cagak (FL) tuna mata besar yang tertangkap longline tuna dari Cilacap bulan Agustus 2001

Figure 2. L Length (FL) distribution of blgeye caught by longliners from Cilacap in August 2001.

dalam penyajian secara grafikal dipilih jenis yang dominan yaitu mata besar sedangkan jenis lain disajikan dalam bentuk kisaran panjang. Jenis mata besar yang tertangkap di perairan Selatan Jawa oleh longline tuna dari Cilacap pada bulan Agustus 2001 memiliki ukuran panjang cagak (FL) berkisar antara $101-160 \mathrm{~cm}$ (Gambar 2), sedangkan yang tertangkap longline tuna dari Benoa memiliki variasi yang lebih lebar yaitu antara 71-150 cm (Gambar 3).

Pada bulan Nopember dan Desember bigeye tuna yang tertangkap umumnya memiliki ukuran lebih besar baik yang berasal dari Benoa ataupun Muara Baru dengan modus panjang $141-150 \mathrm{~cm}$ dan memiliki panjang maksimum mencapai $180 \mathrm{~cm}$ (Gambar 4 dan 5).

Pengukuran panjang juga dilakukan terhadap jenis ikan tuna yang lain yaitu albakora dan madidihang meskipun jumlahnya tidak banyak, longline tuna dari Cllacap pada bulan Oktober 2001, sebagian besar hasil tangkapannya adalah albakora dengan kisaran panjang cagak $81-120 \mathrm{~cm}$ dan modus panjang antara 101-110 m mencapai 69\% (Gambar 6). 


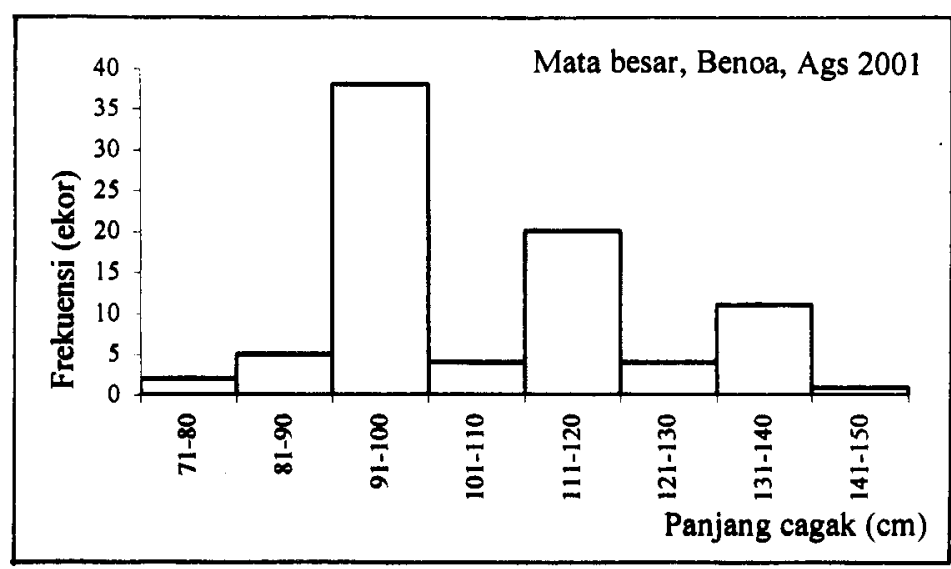

Gambar 3. Sebaran panjang cagak (FL) tuna mata besar yang tertangkap longline tuna dari Benoa, bulan Figure 3. Agustus 2001.

Figure 3. Length (FL) distribution of bigeye caught by longlines from Benoa in August 2001.

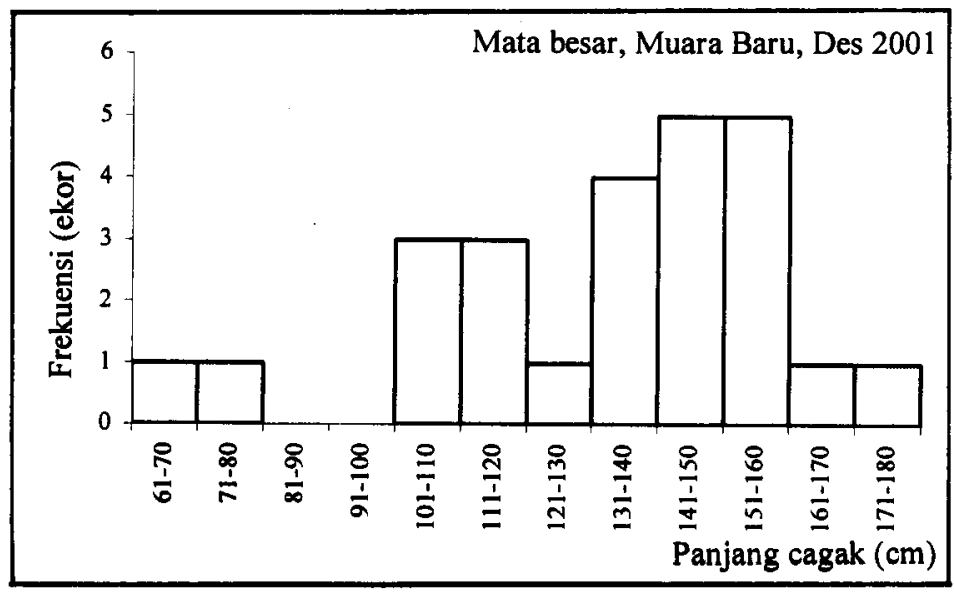

Gambar 4. Sebaran panjang cagak (FL) tuna mata besar yang tertangkap longline tuna dari Muara Baru, Figure 4. Length (FL) distribution of bigeye caught by longliners from Muara Baru in November 2001.

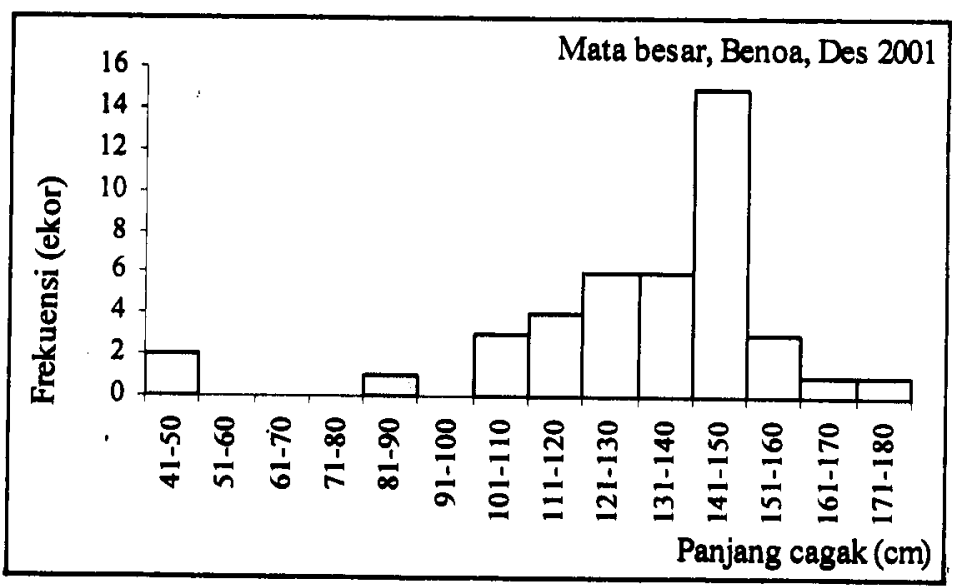

Gambar 5. Sebaran panjang cagak (FL) tuna mata besar yang tertangkap longline tuna darl Benoa, bulan Figure 5. Length (FL) distribution of bigeye tuna caught by longliners from Benoe in December 2001. 


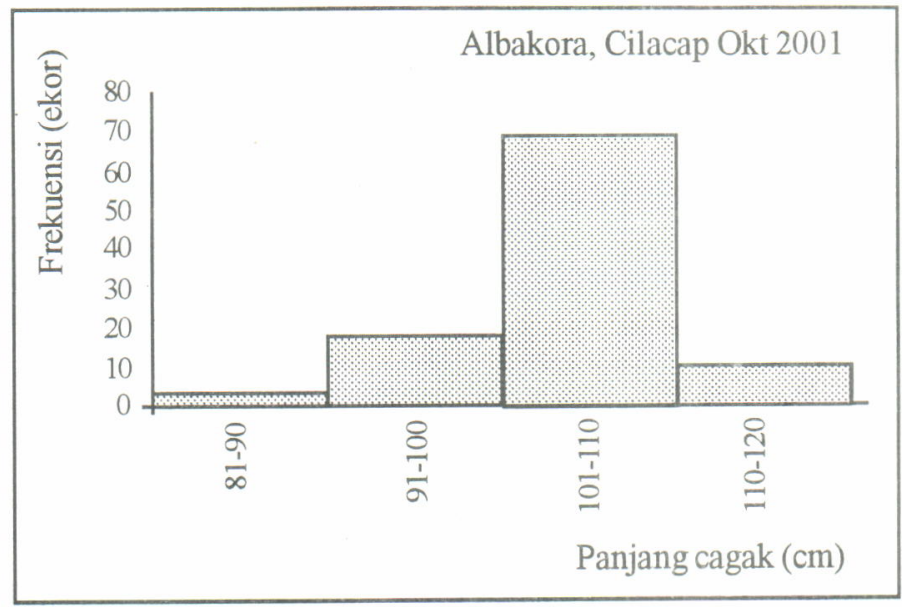

Gambar 6. Sebaran panjang cagak (FL) albakora yang tertangkap longline tuna dari Cilacap, bulan Oktober 2001.

Figure 6. $\quad$ Length (FL) distribution of albacore caught by longliner from Cilacap in October 2001

Sebagian besar ikan madidihang yang tertangkap longline tuna dari Cilacap pada bulan Agustus memiliki panjang cagak (FL) berkisar antara 91-170 $\mathrm{cm}$ (Gambar 7), sedangkan yang tertangkap longline tuna dari Muara Baru pada bulan Nopember pada kisaran $151-160 \mathrm{~cm}$

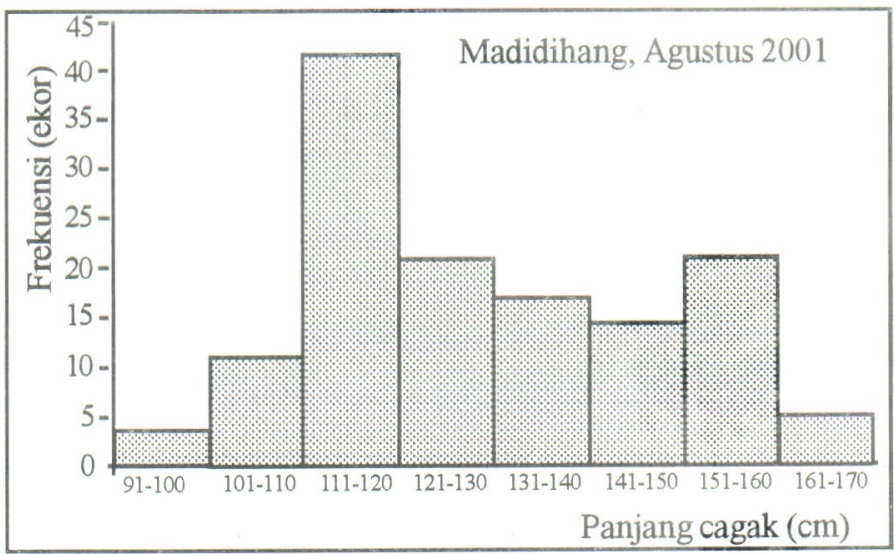

Gambar 7. Sebaran panjang cagak (FL) madidihang yang tertangkap longline tuna dari Cilacap, bulan Figure 7. $\quad$ Length (FL) distribution of yellowfin tuna caught by longliner from Cilacap in August 2001.

Dengan memperhatikan ukuran ikan tuna yang tertangkap menunjukkan bahwa jenis alat tangkap ini menangkap ikan berukuran besar sehingga alat tangkap longline tuna dapat dikatakan cukup selektif terhadap sumber daya ikan tuna.

\section{Aspek Reproduksi}

Pengamatan terhadap aspek reproduksi yang meliputi rasio jenis kelamin dan tingkat kematangan gonad hanya dilakukan terhadap jenis ikan tuna mata besar. Hasil pengamatan rasio jenis kelamin jantan:betina pada bulan Agustus 2001 dari kapal Iongline Cilacap adalah 2:1 (Tabel 2). Ikan tuna mata besar betina sebagian besar memiliki tingkat kematangan gonad IV yakni dengan TKG sebesar $82,75 \%$.
Masing-masing gonad yang diamati ditimbang beratnya dan memiliki kisaran berat antara $2.300-$ 5.100 gram per ekor ikan.

Hasil pengamatan sex ratio tuna mata besar pada bulan Desember 2001 di perairan Samudera Hindia terjadi pergeseran di mana perbandingan jantan dan betina adalah 1:1 (Tabel 3), namun terdapat beberapa ekor ikan yang tidak terdeteksi jenis kelaminnya yaitu sekitar $10 \%$.

Demikian juga dengan hasil pengamatan TKG di mana terjadi perubahan tingkat kematangan mulai TKG II sampai dengan TKG V, namun sebagian besar tuna mata besar memiliki TKG $V$ baik jantan maupun betina. 
Tabel2. Perbandingan jenis kelamin dan TKG tuna mata besar yang tertangkap longline tuna di Samudera Hindia, Agustus 2001

Table 2. Sex ratio and gonad maturity (GM) of bigeye tuna caught by longliners from Indian Ocean in August 2001

\begin{tabular}{|c|c|c|c|c|c|}
\hline $\begin{array}{c}\text { Jenis Kelamin } \\
\text { Sex }\end{array}$ & $\begin{array}{l}\text { Frekuensi } \\
\text { Frequency }\end{array}$ & $\%$ & $\begin{array}{c}\text { TKG } \\
\text { GM } \\
\end{array}$ & $\begin{array}{l}\text { Frekuensi } \\
\text { Frequency }\end{array}$ & $\%$ \\
\hline \multirow[t]{4}{*}{ Betina/Female } & 29 & 34,11 & III & 1 & 3,44 \\
\hline & & & IV & 24 & 82,75 \\
\hline & & & V & 4 & 13,79 \\
\hline & & & Total & 29 & 100,00 \\
\hline Jantan/Male & 56 & 65,89 & & & \\
\hline Total & 85 & 100,00 & & & \\
\hline
\end{tabular}

Tabel 3. Perbandingan jenis kelamin dan TKG tuna mata besar yang tertangkap longline tuna di Samudera Hindia, Desember 2001

Table 3. Sex ratio and gonad maturity (GM) of bigeye tuna caught by Iongliners from Indian Ocean in December 2001

\begin{tabular}{|c|c|c|c|c|c|}
\hline $\begin{array}{c}\text { Jenis Kelamin } \\
\text { Sex }\end{array}$ & $\begin{array}{l}\text { Frekuensi } \\
\text { Frequency }\end{array}$ & $\%$ & $\begin{array}{c}\text { TKG } \\
\text { GM } \\
\end{array}$ & $\begin{array}{l}\text { Frekuensi } \\
\text { Frequency }\end{array}$ & $\%$ \\
\hline \multirow{5}{*}{ Betina/Female } & 18 & 42,86 & II & 2 & 11,11 \\
\hline & & & III & 4 & 22,22 \\
\hline & & & IV & 2 & 11,11 \\
\hline & & & V & 10 & 55,56 \\
\hline & & & Total & 18 & 100,00 \\
\hline \multirow[t]{4}{*}{ Jantan/Male } & 17 & 40,48 & III & 1 & 5,88 \\
\hline & & & IV & 4 & 23,53 \\
\hline & & & V & 12 & 70,59 \\
\hline & & & Total & 17 & 100,00 \\
\hline Immature & 3 & 7,14 & & & \\
\hline tidak teramati/unidenfied & 4 & 9,52 & & & \\
\hline Total & 42 & 100,00 & & & \\
\hline
\end{tabular}

\section{Hubungan Parameter Oseanografi dengan Kelimpahan Tuna}

Suhu permukaan laut di perairan Samudera Hindia sebelah barat Sumatera pada bulan Mei 2001 berkisar antara $29-31^{\circ} \mathrm{C}$. Suhu permukaan tinggi terjadi di perairan sebelah utara antara $1-2^{\circ}$ LS dan bergerak ke selatan menunjukkan penurunan suhu hingga mencapai $29^{\circ} \mathrm{C}$ pada lintang 6-7 $\mathrm{LS}$. Rata-rata salinitas permukaan pada semua stasiun penangkapan adalah 34 permil.

Perairan di sebelah barat daya Selat Sunda pada bulan Nopember memiliki suhu permukaan lebih dingin yaitu berkisar antara $27-29^{\circ} \mathrm{C}$ dan salinitas permukaan berkisar antara 33-34 per mil.

Pada daerah penangkapan di perairan selatan Jawa Tengah pada bulan Agustus 2001 suhu antara $25-27^{\circ} \mathrm{C}$ di mana suhu rendah umumnya di perairan sebelah selatan. Semakin mendekati Pulau Jawa terjadi peningkatan suhu permukaan. Pada saat terjadi suhu rendah di bagian selatan banyak ikan tertangkap di perairan sebelah utara yang memiliki suhu sekitar $27^{\circ} \mathrm{C}$. Sebaliknya pada bulan Desember
2001 suhu permukaan perairan sebelah selatan mengalami peningkatan hingga mencapai $30^{\circ} \mathrm{C}$. Salintas permukaan berkisar antara 34-34,5 per mil. Hubungan antara suhu permukaan laut dengan indeks kelimpahan untuk masing-masing jenis tuna disajikan pada Gambar 8.

Dari Gambar 8 terlihat bahwa setiap jenis ikan tuna memiliki toleransi berbeda-beda terhadap suhu permukaan laut. Indeks kelimpahan madidihang tinggi terjadi pada kisaran suhu permukaan laut 29$31^{\circ} \mathrm{C}$ dan sebaliknya tercatat rendah pada suhu permukaan yang dingin (Gambar $8 \mathrm{~A}$ ). Hal ini menunjukkan bahwa madidihang lebih senang pada suhu perairan yang agak tinggi. Untuk jenis mata besar memiliki indeks kelimpahan tinggi pada selang suhu yang agak lebar yakni antara $26-30^{\circ} \mathrm{C}$, sedangkan pada suhu permukaan antara $24-26^{\circ} \mathrm{C}$, indeks kelimpahan justru menunjukkan penurunan (Gambar 8B). Kejadian sebaliknya terjadi pada jenis ikan albakora dimana memiliki indeks kelimpahan tinggi pada saat suhu permukaan rendah antara 23$24^{\circ} \mathrm{C}$ dan menunjukkan penurunan pada saat suhu permukaan laut meningkat (Gambar $8 \mathrm{C}$ ). 

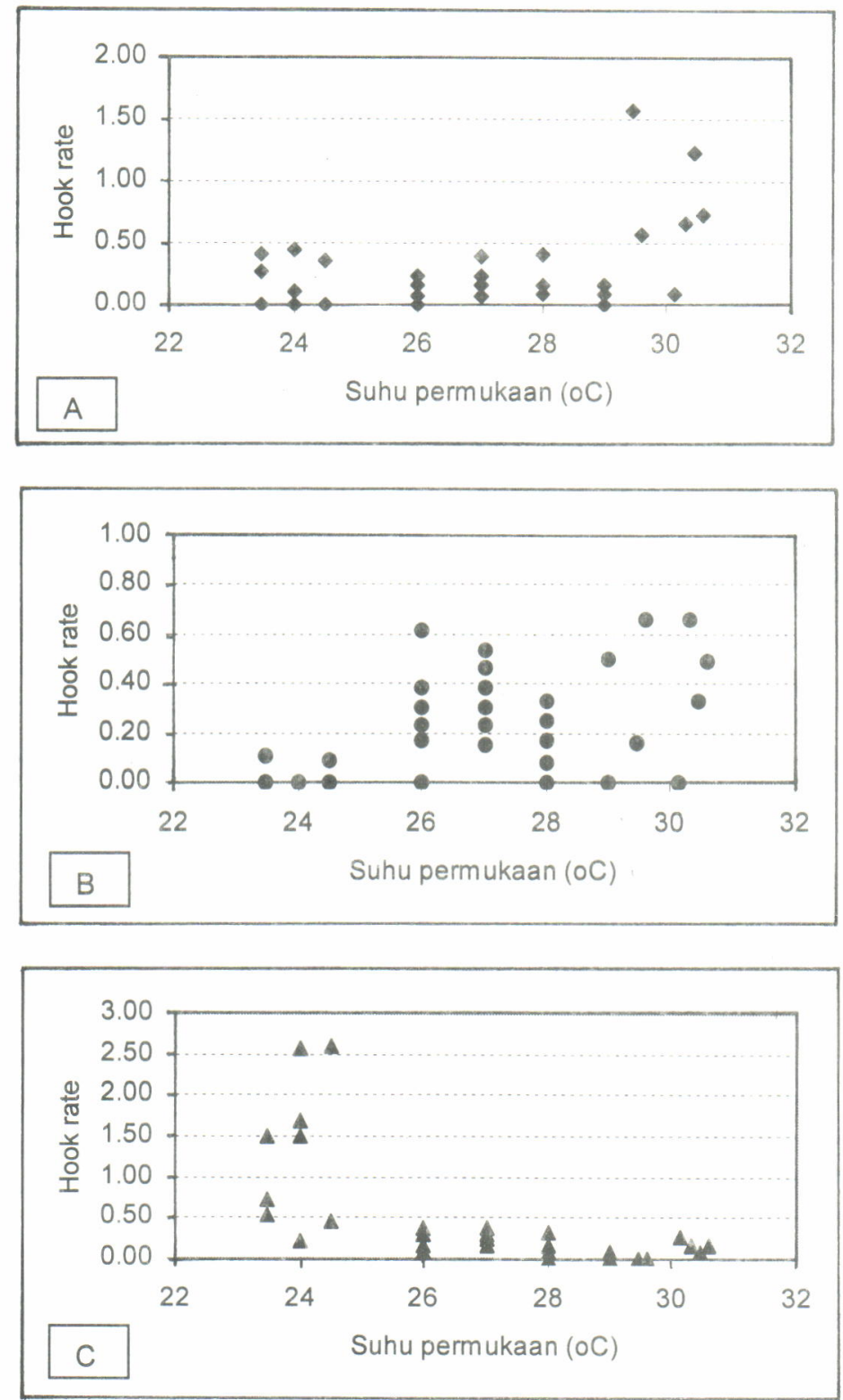

Gambar 8. Hubungan antara suhu permukaan laut dengan indek kelimpahan(hook rate) tuna (A.madidihang; B.mata besar; C. Albakora).

Figure 8. Relationship betwen sea surface temperature and tuna hook rate (A. yelowfin tuna; B. bigeye tuna; C. albacore).

Sebagai indikator kesuburan perairan diamati juga kelimpahan fitoplankton dan zooplankton, meskipun pengamatan tidak dilakukan pada setiap kali trip penangkapan. Hasil pengamatan pada bulan Agustus 2001 di perairan selatan Jawa Tengah menunjukkan kelimpahan fitoplankton berkisar antara 11.923$38.385 \mathrm{sel} / \mathrm{m}^{3}$ dengan jenis dominan adalah Chaetoceros spp. (25\%) dan Rhizosolenea spp. (23\%). Adapun kelimpahan zooplankton berkisar antara 1.076-8.190 individu $/ \mathrm{m}^{3}$ dengan jenis dominan Nauplius spp. mencapai $55 \%$. Dalam tulisan ini hubungan antara kelimpahan plankton dengan kelimpahan ikan tidak dibahas karena data masih sangat terbatas dan diharapkan dapat dilakukan pada penelitian yang akan datang.

\section{KESIMPULAN DAN SARAN}

1. Secara garis besar terdapat 2 daerah penangkapan tuna yaitu di selatan Jawa Tengah dan barat Sumatera. Kapal yang berbasis di Cilacap dan Benoa beroperasi di daerah selatan Jawa Tengah, sedangkan yang dari Muara Baru di perairan barat Sumatera. 
2. Komposisi hasil tangkapan bervariasi tergantung pada waktu dan daerah penangkapan, namun yang dominan pada setiap trip penangkapan adalah jenis tuna mata besar.

3. Ukuran tuna yang tertangkap relatif besar (panjang cagak $40-180 \mathrm{~cm}$ ) sehingga jenis alat tangkap tuna longline tergolong alat yang selektif.

4. Jenis madidihang dan mata besar lebih senang pada suhu permukaan laut yang hangat sedangkan albakora lebih menyukai perairan yang agak dingin.

5. Untuk mengetahui hubungan antara parameter lingkungan dengan penyebaran ikan tuna diperlukan penelitian lebih lanjut secara kontinyu.

\section{DAFTAR PUSTAKA}

Blackburn, M. 1965. Oceanography and the ecology of tunas. Oceanogr. Mar. Biol. Ann. Rev., 3: 299322.

Holden, M. J. \& D. F. S. Raitt. 1974. Manual of fisheries science, Part 2. Methods of resources investigation and their application. FAO. Fish Tech.
Pap. Rev. FAO. Rome, 214 pp

Laevastu, T. \& M. L. Hayes. 1982. Fisheries oceanography and ecology. Fishing News Books Ltd. Farnham, Surrey. England, 199 pp.

Laevastu, T. \& H. Rosa. 1963. Distribution and relative abundance of tunas in relation to their environment. FAO. Fish. Report, 6 (3): 1835-1851.

Longhurst, A. R. \& D. Pauly. 1987. Ecology of tropical ocean. Academic Press Inc. California, 407 pp.

Lurs, R. M., P. C. Fieldler, \& D. R. Montgomey. 1984. Albacore tuna catch distribution relative to environmental features observed from satellites. Deep Sea. Res, 31(9): 1085-1099.

Scott, J. M. 1969. Tuna schooling terminology. Calif. Fish. Game, 55 (2): 136-140.

Simorangkir, S. 2000. Southern bluefin tuna in Bali based Iongline fishery. Indonesia-Australia workshop on shark and tuna. 1-3 Maret 2000, Bali, $8 \mathrm{pp}$.

Squire, J. L. 1982. Catch temperature for some important marine species off California. NOAA. Tech. Report. NMFS-SSRF, 19 pp. 
